\title{
BAYI BERAT LAHIR RENDAH (BBLR) DI PROVINSI JAWA TIMUR TAHUN 2012-2016
}

\author{
Indri Hartiningrum ${ }^{1}$, Nurul Fitriyah ${ }^{2}$ \\ ${ }^{1,2}$ Departemen Biostatistika dan Kependudukan \\ Fakultas Kesehatan Masyarakat Universitas Airlangga \\ Jl. Mulyorejo Kampus C Unair Surabaya 601115 \\ Alamat korespondensi: Indri Hartiningrum \\ Email: indri.hartiningrum05@yahoo.co.id
}

\begin{abstract}
LBW classified as one of children health problems in Indonesia which impacts Infant Mortality Rate (IMR). According to Riskesdas 2010, LBW in Indonesia was noted approximately 11,1\%, while in East Java was noted approximately 10,1\%. This study aims for knowing a pattern of LBW on the 5 years latest in the East Java since that $L B W$ is regarded as the public health indicator because it affects bigger for the children's life in further. This study was descriptive research within quantitative approach using the secondary source from Health Profile of East Java Province during 2012 until 2016. Based on this method, city has a large number of LBW patience are Madiun (8.6\%), Situbondo (5\%) and Bondowoso (4.6\%). Pattern of LBW cases in East Java were fluctuative and did not change to better yet. In conclusion, 3 cities who have the high percentage number of LBW was caused an illness during the women's pregnant and the lack of knowledge about the nutrition proposition. It showed that the program who done by the government for decreasing the number of LBW in East Java was not efficient yet, so, it is needed an intervention in advance.
\end{abstract}

Keywords: LBW (Low Birth Weight), pregnant mother, mortality

\section{ABSTRAK}

Salah satu masalah kesehatan anak yang masih terjadi di Indonesia yaitu BBLR karena Angka Kematian Bayi (AKB) sebagian besar disebabkan oleh BBLR. Berdasarkan Laporan Nasional Riskesdas tahun 2010 kejadian BBLR di Indonesia sebesar 11,1\% sedangkan Provinsi Jawa Timur juga mengalami kejadian BBLR yang cukup tinggi yaitu sebesar $10,1 \%$. Penelitian ini bertujuan untuk mengetahui tren kejadian BBLR 5 tahun terakhir di Provinsi Jawa Timur, melihat bahwa kejadian BBLR dianggap sebagai indikator kesehatan masyarakat karena memiliki dampak besar bagi kehidupan anak di masa depan. Penelitian ini merupakan penelitian deskriptif dengan pendekatan kuantitatif menggunakan data sekunder dari Laporan Profil Kesehatan Provinsi Jawa Timur tahun 2012-2016. Berdasarkan analisa deskriptif Kabupaten/Kota dengan kejadian BBLR tinggi diantaranya yaitu Kota Madiun (8,6\%), Kabupaten Situbondo (5\%) dan Kabupaten Bondowoso (4,6\%). Tren Kejadian BBLR di Provinsi Jawa Timur selama 5 tahun terakhir mengalami fluktuatif dan belum menampakkan perubahan yang lebih baik. Kesimpulannya adalah 3 Kabupaten/Kota memiliki persentase kejadian BBLR yang tinggi disebabkan karena adanya gangguan/penyakit yang menyertai ibu hamil dan pengetahuan yang kurang mengenai asupan gizi. Hal tersebut menunjukan bahwa program yang dilakukan pemerintah untuk menurunkan kejadian BBLR di Provinsi Jawa Timur belum cukup efektif sehingga diperlukan intervensi lebih lanjut.

Kata kunci: BBLR (Berat Bayi Lahir Rendah), ibu hamil, kematian

\section{PENDAHULUAN}

BBLR merupakan salah satu masalah kesehatan yang memerlukan perhatian di berbagai negara terutama pada negara berkembang atau negara dengan sosio-ekonomi rendah. WHO (World Health Organization) mendefinisikan BBLR sebagai bayi yang lahir dengan berat $\leq 2500$ gr. WHO mengelompokkan BBLR menjadi 3 macam, yaitu BBLR (1500-2499 gram), BBLSR (10001499 gram), BBLER (< 1000 gram). WHO juga mengatakan bahwa sebesar 60-80\% dari Angka Kematian Bayi (AKB) yang terjadi, disebabkan karena BBLR. BBLR memiliki risiko lebih besar untuk mengalami morbiditas dan mortalitas daripada bayi lahir yang memiliki berat badan normal. Masa kehamilan yang kurang dari 37 minggu dapat menyebabkan terjadinya komplikasi pada bayi karena pertumbuhan organ-organ yang berada dalam tubuhnya kurang sempurna. Kemungkinan yang terjadi akan lebih buruk bila berat bayi semakin 
rendah. Semakin rendah berat badan bayi, maka semakin penting untuk memantau perkembangannya di minggu-minggu setelah kelahiran.

Berat bayi saat lahir merupakan penentu yang paling penting untuk menentukan peluang bertahan, pertumbuhan, dan perkembangan di masa depannya. Ibu yang selalu menjaga kesehatannya dengan mengkonsumsi makanan bergizi dan menerapkan gaya hidup yang baik akan melahirkan bayi yang sehat, sebaliknya ibu yang mengalami defisiensi gizi memiliki risiko untuk melahirkan BBLR. BBLR tidak hanya mencerminkan situasi kesehatan dan gizi, namun juga menunjukkan tingkat kelangsungan hidup, dan perkembangan psikososialnya.

Bayi dengan BBLR memiliki risiko lebih tinggi mengalami kematian, keterlambatan petumbuhan dan perkembangan selama masa kanak-kanak dibandingkan dengan bayi yang tidak BBLR (Rajashree, 2015). Bayi BBLR memiliki peluang lebih kecil untuk bertahan hidup. Ketika mereka bertahan hidup, mereka lebih rentan terhadap penyakit hingga mereka dewasa. BBLR cenderung mengalami gangguan perkembangan kognitif, retardasi mental serta lebih mudah mengalami infeksi yang dapat mengakibatkan kesakitan atau bahkan kematian. Dampak lain yang muncul pada orang dewasa yang memiliki riwayat BBLR yaitu beresiko menderita penyakit degeneratif yang dapat menyebabkan beban ekonomi individu dan masyarakat (Pramono, 2009).

Berdasarkan data dari World Health Rangkings tahun 2014 dari 172 negara di dunia, Indonesia menempati urutan ke 70 yang memiliki presentase kematian akibat BBLR tertinggi yaitu sebesar $10,69 \%$. Tingkat kelahiran di Indonesia pada tahun 2010 sebesar 4.371.800 dengan kejadian BBLR sebesar 15,5 per 100 kelahiran hidup atau 675.700 kasus prematur dalam 1 tahun (WHO, 2013). Pada tahun 2010, kejadian BBLR di Indonesia sebesar 11,1\% sedangkan Provinsi Jawa Timur juga mengalami kejadian BBLR yang cukup tinggi yaitu sebesar 10,1\% (Kemenkes RI, 2010).

BBLR dapat disebabkan oleh 2 hal yaitu kelahiran prematur atau kelahiran saat usia kehamilan $\leq 37$ minggu dan IUGR yang biasa disebut terganggunya pertumbuhan janin. BBLR dapat menyebabkan kesakitan bahkan kematian. Menetapkan penyebab BBLR antara prematur atau IUGR (Intra Uterine Growth
Restriction) merupakan hal yang penting karena tingkat kematian antara kedua kondisi tersebut berbeda secara signifikan (Astria, et.al., 2016).

Sutan, et.al., (2014) dalam penelitiannya menyatakan bahwa BBLR dapat disebabkan oleh beberapa hal seperti faktor ibu (status gizi, umur, paritas, status ekonomi), riwayat kehamilan buruk (pernah melahirkan BBLR, aborsi), asuhan antenatal care yang buruk, keadaan janin. Wanita dengan status ekonomi rendah cenderung memiliki asupan makanan yang tidak memadai, sanitasi tempat tinggal yang buruk, dan kemampuan untuk mencari perawatan selama kehamilan yang kurang sehingga dapat mempengaruhi berat lahir bayi mereka (Perera \& Manzur, 2014). Usia ibu $\leq 15$ tahun memiliki risiko tinggi untuk melahirkan bayi dengan berat rendah.

Tujuan dari penelitian ini yaitu untuk mengetahui gambaran kejadian BBLR selama 5 tahun terakhir di Provinsi Jawa Timur.

\section{METODE PENELITIAN}

Penelitian ini merupakan penelitian deskriptif dengan pendekatan kuantitatif. Penelitian bersifat non reaktif karena menggunakan data sekunder dari Laporan Profil Kesehatan Provinsi Jawa Timur tahun 20122016.

\section{HASIL PENELITIAN}

Hasil olah statistik antara bayi lahir hidup dengan Kabupaten/Kota dalam lima tahun terakhir (2012-2016) telah disajikan dalam bentuk diagram batang yang dapat dilihat pada gambar 1. Bayi lahir hidup di Provinsi Jawa Timur apabila ditotal selama 5 tahun terakhir yaitu sebesar 2.971.951 jiwa. Kabupaten/Kota yang memiliki angka bayi lahir hidup tertinggi diantaranya yaitu Kota Surabaya (213.097 jiwa), Kabupaten Malang (206.204 jiwa) dan Kabupaten Jember (181.955 jiwa). Kabupaten/Kota yang memiliki angka bayi lahir hidup rendah diantaranya Kota Mojokerto (10.270 jiwa), Kota Blitar (10.632 jiwa), Kota Batu (15.606 jiwa).

Hasil olah statistik antara kejadian BBLR dengan Kabupaten/Kota dalam 5 tahun terakhir (2012-2016) telah disajikan dalam bentuk diagram batang dan dapat dilihat pada gambar 2. Kejadian BBLR di Provinsi Jawa Timur apabila ditotal selama 5 tahun terakhir yaitu sebesar 2,8\%. Kabupaten/Kota dengan angka 
kejadian BBLR yang relatif jauh dengan angka kejadian BBLR Provinsi Jawa Timur, diantaranya Kota Madiun (8,6\%), Kabupaten Situbondo (5\%), dan Kabupaten Bondowoso $(4,6 \%)$. Kabupaten/Kota yang memiliki angka kejadian BBLR rendah, diantaranya Kabupaten Sidoarjo (1,2\%), Kabupaten Bangkalan (1,4\%), dan Kabupaten Lamongan (1,8\%).

Berdasarkan data yang terdapat pada laporan Profil Kesehatan Provinsi Jawa Timur, maka dilakukan pengolahan data kemudian menganalisis data tersebut untuk mengetahui tren kejadian BBLR di Provinsi Jawa Timur dari tahun 2012-2016 seperti yang telah disajikan dalam bentuk grafik pada gambar 3 . Gambar 3 menunjukkan bahwa tren kejadian BBLR selama 5 tahun terakhir mengalami fluktuatif dan mengalami penurunan yang signifikan pada tahun $2014(3,3 \%)$ menjadi $(0,3 \%)$ pada tahun 2015. Tahun 2016 kejadian BBLR mengalami peningkatan yang lebih besar jika dibandingkan dengan tahun sebelumnya yaitu sebesar $(3,6 \%)$. Tentunya hal tersebut sangat memprihatinkan melihat peningkatan yang terjadi lebih dari 2 kali lipat dibandingkan tahun sebelumnya.

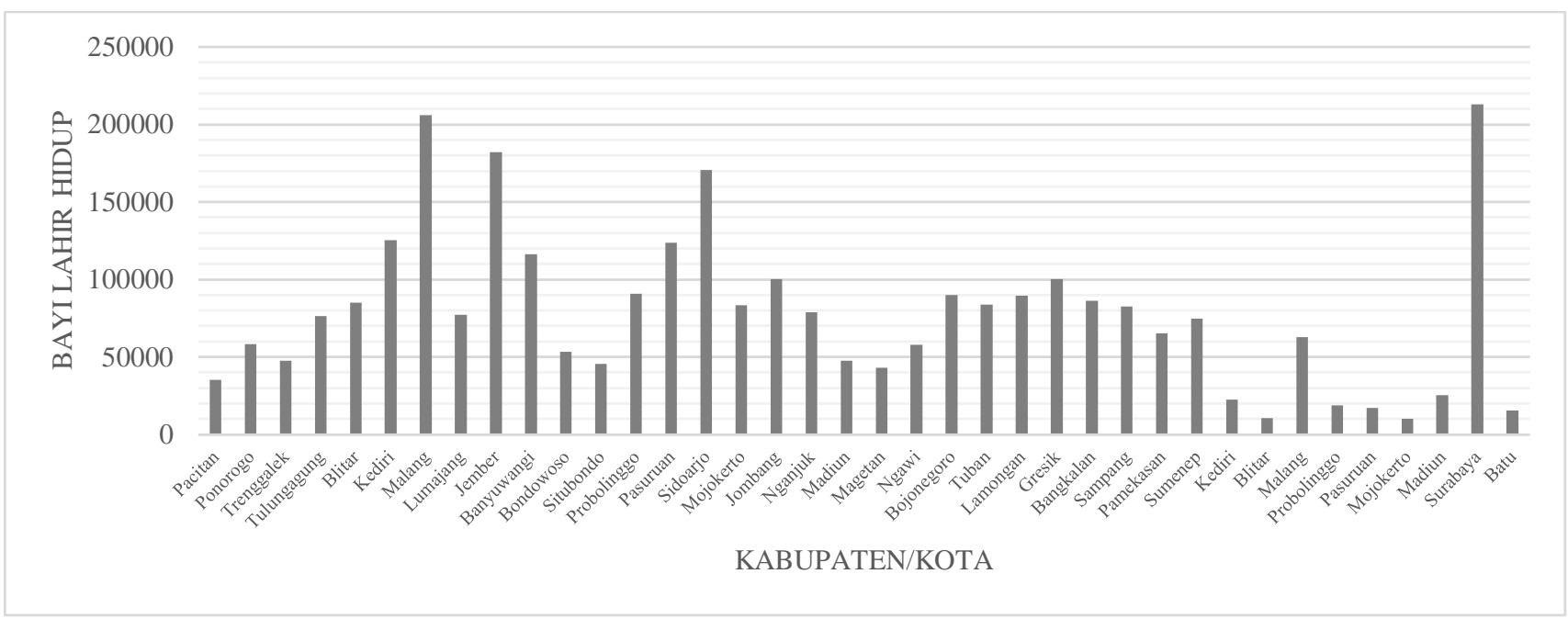

Gambar 1. Bayi Lahir Hidup Selama 5 Tahun Terakhir Tahun 2012-2016 di Provinsi Jawa Timur

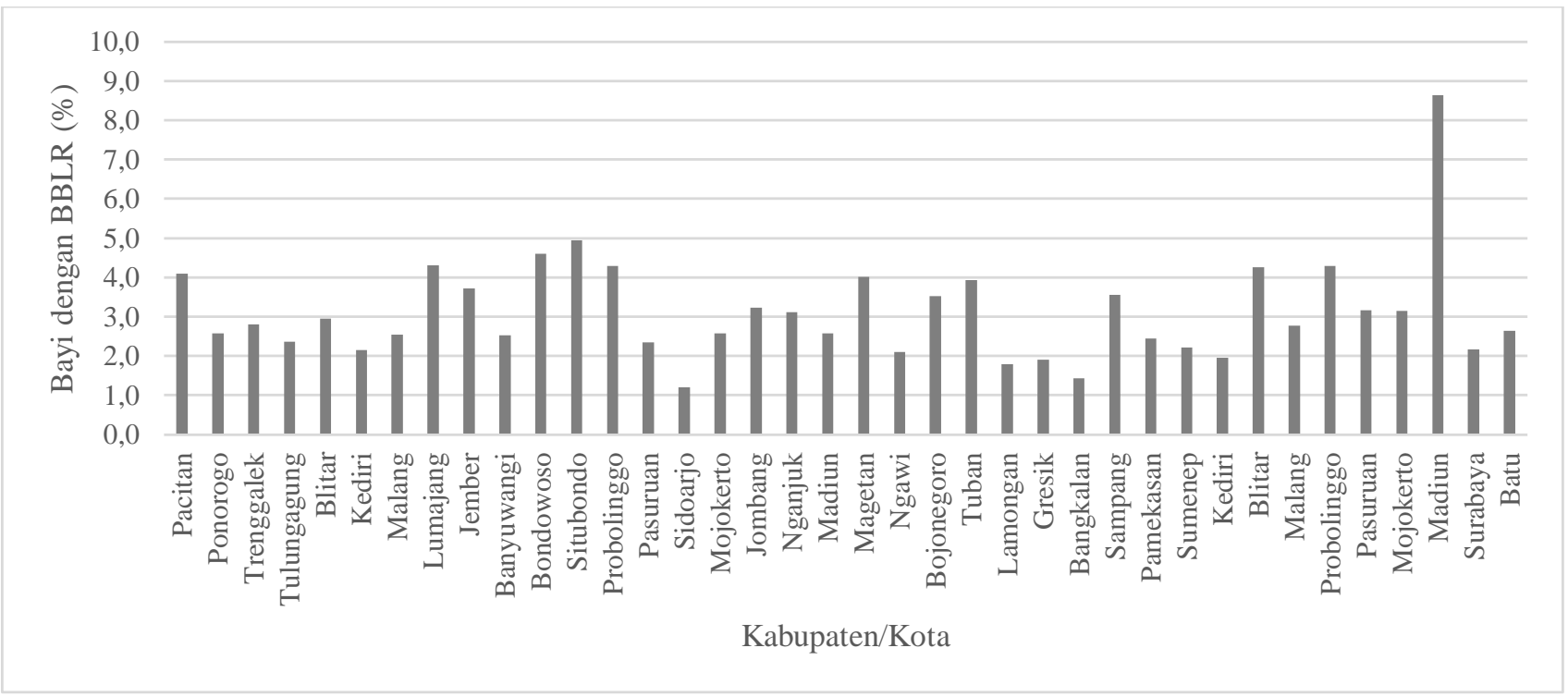

Gambar 2. Kejadian BBLR Selama 5 Tahun Terakhir Tahun 2012-2016 di Provinsi Jawa Timur 


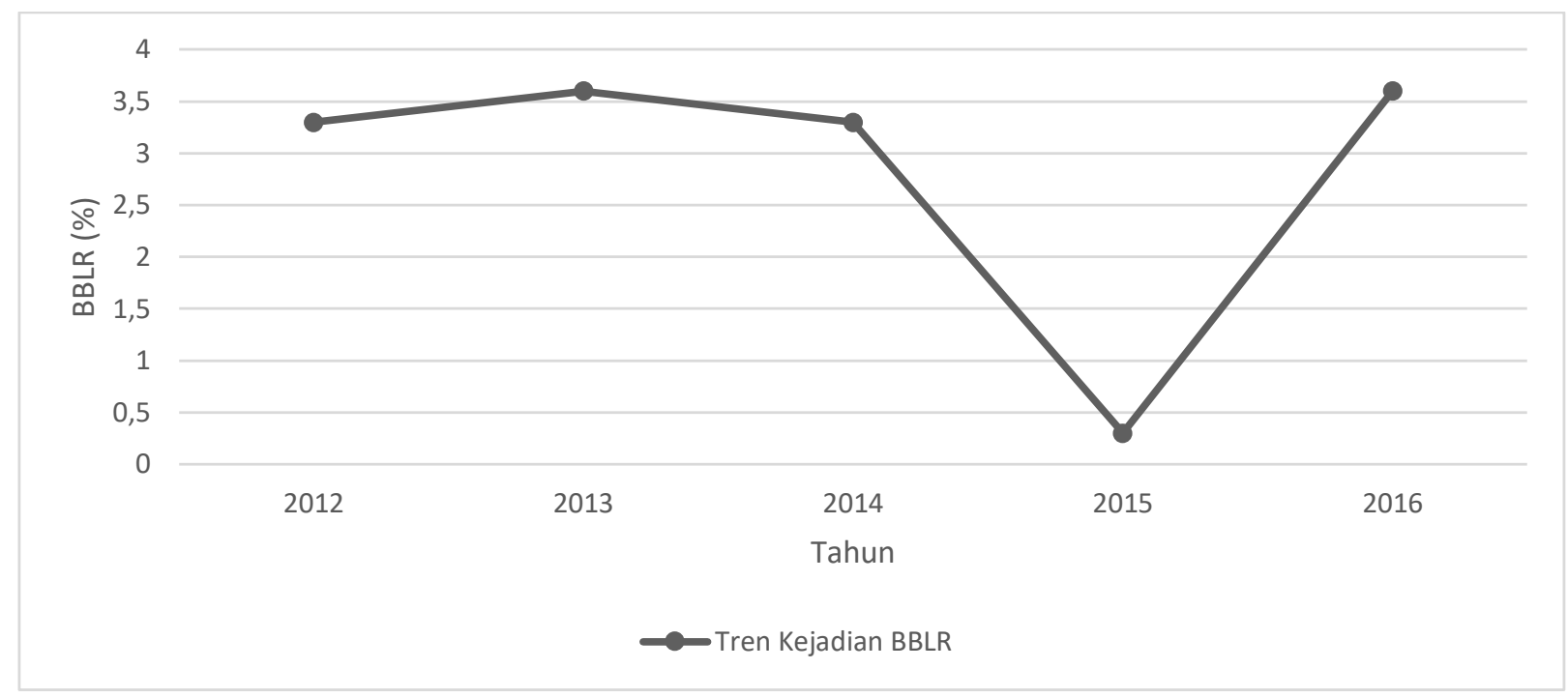

Gambar 3. Tren Kejadian BBLR di Provinsi Jawa Timur Tahun 2012-2016

\section{PEMBAHASAN}

\section{Kejadian BBLR di Provinsi Jawa Timur}

Hasil olah statistik yang terdapat pada grafik diatas menunjukkan bahwa dari 38 Kabupaten/Kota di Jawa Timur yang memiliki angka bayi lahir hidup tertinggi yaitu Kota Surabaya, Kabupaten Malang, dan Kabupaten Jember. Sedangkan pada gambar 2 menunjukkan bahwa dari 38 Kabupaten/Kota di Jawa Timur yang memiliki persentase tinggi kejadian BBLR diantaranya adalah Kota Madiun, Kabupaten Situbondo dan Kabupaten Bondowoso. Berdasarkan Laporan Profil Kesehatan dari Kota Madiun, Kabupaten Situbondo, dan Kabupaten Bondowoso pada tahun 2015 dan 2014 tersebut penyebab kejadian BBLR memiliki kesamaan yaitu disebabkan karena adanya suatu gangguan atau penyakit yang menyertai ibu hamil seperti anemia, Kekurangan Energi Kronis (KEK), preeklamsia/eklamsia, gemelli (kehamilan ganda) dan lainnya sehingga mengakibatkan bayi lahir sebelum waktunya dengan berat kurang dari 2500 gram. Pendidikan bagi ibu hamil tentang gizi seimbang, perawatan bayi dengan BBLR, menyusui bayi secara eksklusif diberikan pada waktu pelaksanaan kelas ibu hamil ditujukan untuk menekan angka kematian bayi oleh karena BBLR. Pemberian asupan gizi pada 1000 Hari Pertama Kehidupan (HPK) perlu di sosialisasikan dan lebih ditingkatkan pelaksanaannya pada masyarakat guna kelangsungan hidup bayi agar menjadi generasi yang sehat dan cerdas (Kemenkes RI, 2017).
Penyebab tingginya BBLR di 3 Kabupaten/Kota di Jawa Timur sejalan dengan hasil penelitian Merzaila (2012) yang mengatakan bahwa ibu hamil yang mengalami anemia berisiko 4 kali lebih besar untuk melahirkan BBLR. Kejadian anemia yang dialami ibu hamil akan meningkat seiring bertambahnya usia kehamilan. Hal tersebut dapat terjadi karena terdapat ketidakseimbangan antara jumlah plasma darah dan sel darah merah yang terdapat pada tubuh ibu hamil. Ketidakseimbangan tersebut dapat dilihat dari turunnya kadar hemoglobin $(\mathrm{Hb})$. Saat usia kehamilan memasuki trimester 3 maka tubuh membutuhkan asupan zat besi yang lebih banyak karena pada saat tersebut janin mengalami pertumbuhan yang lebih cepat, sehingga apabila terjadi ketidakseimbangan dalam tubuh yang ditandai oleh rendahnya kadar $\mathrm{Hb}$ maka akan berpengaruh pada jalannya oksigen dalam rahim kemudian merusak kondisi intrauterin tertutama plasenta sehingga terlihat tidak sebagaimana mestinya yang dapat menyebabkan terganggunya perkembangan janin sehingga ibu melahirkan anak dengan BBLR. Hb pada ibu hamil dikatakan rendah apabila <11g (Kalady, et.al., 2016). Wijaya (2013) juga menjelaskan bahwa ibu yang menderita anemia saat hamil mempunyai peluang sebesar 9,778 kali untuk melahirkan anak dengan BBLR. Asupan nutrisi yang baik selama kehamilan dapat mencegah terjadinya anemia pada ibu hamil. Apabila selama masa kehamilan ibu tidak mengalami anemia, metabolisme tubuh dapat bekerja secara optimal 
dan nutrisi yang dibutuhkan selama kehamilan dapat terpenuhi untuk menghindari terjadinya BBLR.

Kebutuhan energi dan protein yang tidak tercukupi pada ibu hamil dapat mengakibatkan terjadinya KEK. Ibu hamil yang mengalami KEK berisiko melahirkan anak dengan BBLR dari pada ibu yang tidak mengalami KEK. KEK juga merupakan penyebab tidak langsung kematian ibu. Ibu hamil yang memiliki Lingkar Lengan Atas (LILA) $<23,5 \mathrm{~cm}$, sebaiknya diberikan makanan tambahan karena beresiko mengalami KEK (Kemenkes RI, 2017). Hal ini karena ibu hamil yang kekurangan energi tidak memiliki simpanan zat gizi untuk menyuplai kebutuhan fisiologi kehamilan seperti kelainan pada hormon dan volume darah untuk janin sehingga pertumbuhan dan perkembangan janin dapat terganggu sehingga lahir dengan BBLR. Perlunya penyuluhan terkait penyakit KEK pada ibu-ibu yang baru menikah supaya lebih memperhatikan kondisi fisiknya sebelumnya hamil seperti asupan gizi yang terpenuhi dan memiliki LILA yang cukup. Ibu yang memiliki LILA < 23,5 cm disarankan untuk meningkatkan asupan gizi serta menunda kehamilannya terlebih dahulu supaya risiko untuk melahirkan BBLR rendah. Ibu hamil yang telah mengalami KEK sebaiknya disarankan untuk meningkatkan asupan gizi dengan mengkonsumsi makanan yang tinggi kalori dan protein (Suryati, 2014). Penelitian Darmayanti (2015) menjelaskan bahwa ibu hamil yang menderita KEK memiliki peluang sebesar 2,8 kali untuk melahirkan bayi dengan berat badan rendah.

Berdasarkan laporan profil kesehatan dari 3 kabupaten/kota telah ditemukan kejadian BBLR yang disebabkan oleh preeklamsi pada ibu hamil. Ibu dengan preeklamsi akan mengalami perubahan fisiologi diantaranya plasenta dan uterus yang mengalami perubahan dimana aliran darah yang menurun pada plasenta dapat menyebabkan terganggunya fungsi plasenta. Plasenta yang tidak berfungsi sebagaimana mestinya dapat menyebabkan janin kekurangan gizi sehingga memiliki resiko untuk lahir dengan berat badan rendah (BBLR) (Lapidus, 2010).

Gemelli atau kehamilan ganda merupakan masalah kesehatan yang memiliki risiko tinggi terhadap kelangsungan hidup ibu dan bayi. Kehamilan ganda dapat menyebabkan tingginya kejadian IUGR (Intra Uterine Growth Restriction). Berat badan kehamilan kembar seringkali lebih rendah daripada kehamilan tunggal karena persalinan yang terjadi sebelum cukup bulan. Uterus yang mengalami penegangan berlebihan biasanya karena besarnya janin, adanya 2 plasenta, serta air ketuban yang berlebih sehingga dapat menyebabkan terjadinya persalinan 3 minggu sebelum cukup bulan. Ketidaknyamanan fisik seperti pembengkakan pada kaki, sesak nafas, anemia, punggung terasa sakit, dan plasenta previa dapat terjadi pada ibu yang mengalami kehamilan ganda sehingga dibutuhkan perawatan yang lebih intensif. Pada kehamilan ganda ibu membutuhkan nutrisi yang tinggi. Jika terjadi kekurangan nutrisi maka pertumbuhan janin akan terhambat (Ladewig, 2013). Fadlun \& Achmad (2011) mengemukakan bahwa kehamilan kembar lebih berisiko untuk mengalami gangguan seperti penegangan uterus yang berlebihan yang disebabkan karena besarnya ukuran janin, terdapatnya dua plasenta dan air ketuban yang berlebihan sehingga menyebabkan kelahiran prematur. Hal tersebut menunjukkan bahwa kehamilan kembar (gemeli) lebih berisiko mengalami BBLR daripada kehamilan tunggal.

Peran seorang wanita terutama Ibu sangat penting dalam menjaga, memperhatikan dan merawat kesehatan keluarganya seperti menyiapkan makanan bergizi setiap hari, bertanggung jawab terhadap kebersihan rumah serta menciptakan pola hidup sehat baik secara jasmani, rohani maupun sosial. Terutama pada masa 1000 HPK, bagi wanita yang tengah mempersiapkan kehamilan, penting bagi mereka untuk mengetahui tentang gizi seimbang mulai dari awal kehamilan sampai anak usia dua tahun agar bayi lahir sehat serta terhindar dari kejadian BBLR (Widyastuti, et.al., 2009). Kerjasama kedua orang tua supaya dapat menciptakan pola hidup yang sehat sangat diperlukan.

Kabupaten/Kota yang memiliki persentase rendah kejadian BBLR adalah Kabupaten Sidoarjo, Kabupaten Bangkalan dan Kabupaten Lamongan. Berdasarkan Laporan Profil Kesehatan dari 3 Kabupaten/Kota tersebut, kejadian BBLR rendah disebabkan karena meningkatnya cakupan pelayanan antenatal care dan status gizi ibu hamil yang baik. Hal tersebut menunjukkan bahwa masyarakat telah menyadari bahwa pentingnya memperhatikan kebutuhan gizi selama hamil serta melakukan pemeriksaan antenatal care secara teratur. Hal tersebut juga tidak lepas dari kerja keras dari 
petugas kesehatan yang telah melakukan penyuluhan terhadap masyarakat tentang pentingnya melakukan pemeriksaan antenatal care dan pentingnya memperhatikan asupan gizi saat kehamilan.

\section{Tren Kejadian BBLR di Provinsi Jawa Timur}

Selama masa kehamilan, ibu harus memeriksakan kehamilannya secara teratur pada fasilitas kesehatan terdekat supaya dapat memantau perkembangan janin sehingga dapat melahirkan bayi yang sehat baik secara jasmani maupun rohani. Peraturan Menteri Kesehatan RI Nomor 97 Tahun 2014 yang mengemukakan bahwa selama masa kehamilan, seorang ibu harus memperoleh pelayanan antenatal minimal 4 kali dengan rincian masing-masing 1 kali pada usia kehamilan memasuki trimester I dan trimester II, kemudian 2 kali pada trimester III. Hasil statistik pada tabel 2 menunjukkan bahwa tren kejadian BBLR tahun 2012-2016 mengalami fluktuatif. Terjadi peningkatan pada tahun 2015 dimana persentase kejadian BBLR sebesar $0,3 \%$ menjadi sebesar $3,6 \%$ pada tahun 2016. Tren peningkatan yang terjadi setiap tahun dapat berdampak pada terjadinya peningkatan angka kesakitan dan angka kematian neonatal di Provinsi Jawa Timur. Perlunya suatu kebijakan yang efektif supaya dapat menurunkan angka kejadian BBLR.

Hambatan yang masih ditemukan pada lapangan saat melakukan upaya penurunan angka kejadian BBLR adalah perilaku masyarakat setempat yang tidak mendukung upaya penurunan angka kejadian BBLR seperti tidak melakukan pemeriksaan kehamilan (antenatal care) secara rutin. Cakupan K4 selama 6 tahun terakhir hanya sebesar 73\%$80,44 \%$ yang artinya belum pernah mencapai target nasional yaitu sebesar 94\% (Dinkes Kabupaten Situbondo, 2015). Antenatal Care berperan penting dalam mencegah dan mendeteksi komplikasi yang terjadi terhadap ibu dan bayi termasuk resiko BBLR. Pelayanan antenal care merupakan salah satu program kesehatan masyarakat khususnya program KIA (Aja, 2014). Apabila BBLR tidak mendapat penanganan dengan benar maka dapat berpengaruh pada pertumbuhan dan perkembangan kognitifnya di masa depan.

Pengetahuan masyarakat yang rendah tentang bayi risiko tinggi tertutama BBLR juga menjadi hambatan untuk menurunkan angka kejadian BBLR (Dinkes Kabupaten Situbondo,
2015). Pengetahuan yang rendah cenderung memiliki kebiasaan atau pola hidup yang buruk seperti makan makanan yang tidak bergizi, memeriksakan kehamilan hanya apabila ada keluhan, mencari dan memilih penolong persalinan yang murah seperti ke dukun tanpa mengetahui akibat dari pertolongan persalinan yang menggunakan alat tidak steril. Sebaliknya, pengetahuan yang tinggi dapat menunjang perilaku hidup sehat. Pengetahuan sangat diperlukan dalam semua hal terutama kesehatan karena pengetahuan adalah sebuah proses dalam mencapai suatu perilaku kesehatan. Notoadmodjo (2010) mengatakan bahwa perubahan perilaku atau tindakan tersebut dilihat berdasarkan pengetahuan dan kesadaran melalui pengalaman yang dilalui sehingga diharapkan menjadi pembelajaran untuk lebih baik kedepannya. Hal tersebut menunjukkan bahwa pentingnya pengetahuan seseorang mengenai masalah kesehatan terutama BBLR.

Hambatan lain yang masih terjadi dalam upaya menurunkan angka kejadian BBLR yaitu kurangnya dukungan dan partisipasi tenaga kesehatan karena banyak yang tidak mematuhi SOP. Dukungan dan partisipasi yang kurang disebabkan karena belum semua tenaga kesehatan mengikuti pelatihan mengenai manajemen BBLR (Dinkes Kabupaten Situbondo, 2015). Pelatihan mengenai managemen BBLR bagi tenaga kesehatan dapat memberikan banyak dampak positif terutama bila pelatihan tersebut diadakan secara teratur. Tenaga kesehatan menjadi lebih kompeten dalam menangani kasus BBLR. Ibu yang memiliki bayi dengan kondisi BBLR tentunya memerlukan dukungan orang sekitar terutama dukungan tenaga kesehatan dalam merawat bayi terutama masa awal setelah persalinan. Dukungan yang dapat diberikan oleh tenaga kesehatan yaitu dukungan edukasi seperti cara merawat bayi yang mengalami BBLR, dukungan emosional seperti memberikan semangat dan motivasi supaya ibu tidak putus asa atau khawatir dalam merawat bayinya, dan dukungan sarana prasarana seperti alat khusus yang digunakan untuk bayi yang mengalami BBLR. Mendapat dukungan oleh orang sekitar akan membuat si ibu menjadi lebih percaya diri dalam merawat anak.

Hambatan lain yang menyebabkan tingginya angka kejadian BBLR yaitu perilaku dan budaya dari masyarakat setempat yang tidak mendukung upaya penurunan AKB seperti pengambilan keputusan yang terlambat 
(Dinkes Kabupaten Situbondo, 2015). Selain itu masih adanya kepercayaan masyarakat terhadap orang yang dituakan. Hasil penelitian Khasanah (2011) menyatakan bahwa disadari atau tidak, faktor kepercayaan budaya setempat serta pengetahuan masyarakat seperti pantangan perilaku yang tidak boleh dilakukan saat hamil (kepercayaan mengenai wanita hamil yang duduk di pintu rumah akan susah melahirkan) maupun makanan yang tidak boleh dimakan saat hamil (memakan ikan dapat menyebabkan ASI menjadi amis) atau kebiasaan lain dapat memberikan dampak bagi kesehatan ibu dan janin baik dampak positif maupun negatif. Kepercayaan pantang terhadap makanan yang sebenarnya dibutuhkan bagi ibu hamil dapat menyebabkan ibu kehilangan zat gizi yang berkualitas serta beresiko untuk timbulnya berbagai penyakit seperti anemia, KEK dan lain sebagainya. Status ekonomi juga berperan penting terhadap pengetahuan dan informasi yang didapat dalam menghadapi kehamilan.

\section{SIMPULAN DAN SARAN}

\section{Simpulan}

Kejadian BBLR di Provinsi Jawa Timur dalam 5 tahun terakhir yaitu sebesar 2,8\%. Kabupaten/Kota yang kejadian BBLRnya jauh dari rata-rata, diantaranya Kota Madiun $(8,6 \%)$, Kabupaten Situbondo (5\%), dan Kabupaten Bondowoso (4,6\%). Berdasarkan Laporan Profil Kesehatan dari 3 Kabupaten/Kota tersebut menyatakan bahwa angka kejadian BBLR yang tinggi disebabkan karena adanya gangguan atau penyakit yang menyertai ibu hamil seperti anemia, gemelli, preeklamsi/eklamsi dan lainnya. Tren Kejadian BBLR di Provinsi Jawa Timur dalam 5 tahun terakhir mengalami fluktuatif dan belum menampakkan perubahan yang lebih baik. Terjadi peningkatan pada tahun 2015 dimana persentase kejadian BBLR sebesar 0,3\% menjadi sebesar 3,6\% pada tahun 2016.

\section{Saran}

Pemerintah perlu mengadakan pelatihanpelatihan mengenai managemen BBLR secara rutin kepada tenaga kesehatan untuk meningkatkan kompetensi para tenaga kesehatan. Tenaga Kesehatan perlu meningkatkan cakupan kunjungan pemeriksaan kehamilan (antenatal care) supaya dapat mengurangi risiko komplikasi pada ibu hamil sejak dini sehingga dapat menurunkan angka kematian dan kesakitan pada ibu dan bayi terutama kejadian BBLR.

\section{DAFTAR PUSTAKA}

Aja, N. 2014. Hubungan Kunjungan Pemeriksaan Kehamilan K4 dengan Kejadian Bayi Berat Lahir Rendah di Kota Ternate. Tesis. Universitas Gadjah Mada.

Astria, Y., Christopher, S.S., Benedicta, M.S., Felix, F.W., Rinawati, R. 2016. Low Birth Weight Profiles at H. Boejasin Hospital South Borneo, Indonesia in 2010-2012. Paediatrica Indonesiana, [e-journal] 56 (3): pp. 155-161.

Darmayanti, L. 2015. Hubungan antara Status KEK dan Status Anemia dengan Kejadian BBLR pada Ibu Hamil Usia Remaja (Studi di Wilayah Kerja Puskesmas Cerme Kabupaten Bondowoso). Skripsi. Universitas Jember.

Dinkes Kabupaten Bondowoso. 2016. Profil Kesehatan Kabupaten Bondowoso 2015. Bondowoso: Dinas Kesehatan Kabupaten Bondowoso.

Dinkes Kabupaten Situbondo. 2015. Profil Kesehatan Kabupaten Situbondo 2014. Situbondo: Dinas Kesehatan Kabupaten Situbondo.

Dinkes Kota Madiun. 2016. Profil Kesehatan Kota Madiun 2015. Madiun: Dinas Kesehatan Kota Madiun.

Dinkes Provinsi Jawa Timur. 2013. Profil Kesehatan Provinsi Jawa Timur 2012. Surabaya: Dinas Kesehatan Provinsi Jawa Timur.

Dinkes Provinsi Jawa Timur. 2014. Profil Kesehatan Provinsi Jawa Timur 2013. Surabaya: Dinas Kesehatan Provinsi Jawa Timur.

Dinkes Provinsi Jawa Timur. 2015. Profil Kesehatan Provinsi Jawa Timur 2014. Surabaya: Dinas Kesehatan Provinsi Jawa Timur.

Dinkes Provinsi Jawa Timur. 2016. Profil Kesehatan Provinsi Jawa Timur 2015. Surabaya: Dinas Kesehatan Provinsi Jawa Timur.

Dinkes Provinsi Jawa Timur. 2017. Profil Kesehatan Provinsi Jawa Timur 2016. Surabaya: Dinas Kesehatan Provinsi Jawa Timur.

Fadlun, Achmad, F. 2011. Asuhan Kebidanan Patologis. Jakarta: Salemba Medika. 
Kalady, M.A., Sunilbala, K., Y. Tomba, S., Nabakishore, S., Iainehskhem, L.M., Syarif, A. 2016. Effect of Maternal Anemia on Birth Weight of Term Babies in A Tertiary Care Hospital, Manipur. IOSR Journal of Dental and Medical Sciences, [e-journal] 15 (12), Ver. VI: pp. 39-41.

Kemenkes RI. 2010. Laporan Nasional Riset Kesehatan Dasar 2010. Jakarta: Badan Penelitian dan Pengembangan Kesehatan Departemen Kesehatan Republik Indonesia.

Kemenkes RI. 2017. Profil Kesehatan Indonesia Tahun 2016. Jakarta: Kementerian Kesehatan Republik Indonesia.

Khasanah, N. 2011. Dampak Persepsi Budaya terhadap Kesehatan Reproduksi Ibu dan Anak di Indonesia. Muwazah, [e-journal] 3 (2): pp. 487-492.

Ladewig, W.P. 2013. Asuhan Keperawatan Ibu pada Bayi Baru Lahir. Jakarta: Penerbit Buku Kedokteran EGC.

Lapidus, A.M. 2010. Effects of Preeclamsia on the Mother, Fetus, and Child. Review Article in Gynecology Forum, 4 (1).

Merzaila, N. 2012. Determinan Kejadian Berat Badan Lahir Rendah (BBLR) di Kabupaten Belitung Timur Provinsi Kepulauan Bangka Belitung Tahun 2010-2011. Skripsi. Universitas Indonesia.

Notoatmodjo, S. 2010. Promosi Kesehatan Teori \& Aplikasi Edisi Revisi 2010. Jakarta: Rineka Cipta.

Peraturan Menteri Kesehatan Nomor 97 tahun 2014 tentang Pelayanan Kesehatan Masa Sebelum Hamil, Masa Hamil, dan Masa Sesudah Melahirkan, Penyelenggaraan Pelayanan Kontrasepsi, serta Pelayanan Kesehatan Seksual. Jakarta: Kementerian Kesehatan Republik Indonesia.
Perera, K.P.N., Manzur, K. 2014. SocioEconomic and Nutritional Determinants of Low Birth Weight in India. North American Journal of Medical Sciences, [e-journal] 6 (7): pp. 302-308.

Pramono, S. 2009. Risk Factor Occurrence Low Birth Weight According Social Determinant, Economic, and Demographic Indonesia. Health System Research Bulletin.

Rajashree, K. 2015. Study on the Factors Associated with Low Birth Weight among Newborns Delivered in a Tertiary-Care Hospital, Shimoga, Karnataka. International Journal of Medical Science and Public Health, [e-journal] 4 (9): pp. 1287-1290.

Suryati. 2014. Faktor-Faktor yang Mempengaruhi Kejadian BBLR di Wilayah Kerja Puskesmas Air Dingin Tahun 2013. Jurnal Kesehatan Masyarakat Andalas, [ejournal] 8 (2): pp. 72-78.

Sutan, R., Mazlina, M., Aimi, N.M., Azmi, M.T. 2014. Determinant of Low Birth Weight Infants: A Matched Case Control Study. Open Journal of Preventive Medicine, [e-journal] 4 (3): pp. 91-99.

Wijaya, R.S. 2013. Hubungan Anemia pada Ibu Hamil dengan Kejadian Bayi Berat Lahir Rendah di Rumah Sakit Umum Daerah Raden Mattaher Jambi Periode 19 April-31 Mei 2013. Artikel Ilmiah. Universitas Jambi. Widyastuti, Y., Anita, R., Yuliasti, E.P. 2009. Kesehatan Reproduksi. Yogyakarta: Fitramaya.

WHO. 2013. Materi Pembelajaran Kesehatan Ibu \& Anak. Edukia 2013.

WHO. 2014. Low Bitrh Weight. [online] http://www.worldlifeexpentancy.com/cause -of-death/low-birth-weight/by-country/. 